\title{
Syntheses, Characterization and Crystal Structures of Schiff Base Zinc(II) Complexes with Antibacterial Activity
}

\author{
Dong-Lai Peng1, ${ }^{*}$ and Nan Sun ${ }^{2}$ \\ ${ }^{1}$ Key Laboratory of Surface and Interface Science of Henan Province, School of Material \& Chemical Engineering, Zhengzhou \\ University of Light Industry, Zhengzhou 450001, P.R. China \\ ${ }^{2}$ College of Chemistry, Chemical Engineering and Material Science, Shandong Normal University, \\ Jinan 250014, P.R. China \\ *Corresponding author: E-mail: pengdonglai2015@sina.com
}

Received: 17-06-2018

\begin{abstract}
Two polynuclear zinc(II) complexes, $\left[\mathrm{Zn}_{2}\left(\mathrm{~L}^{1}\right)_{2}\left(\mathrm{OH}_{2}\right)_{2}\right](\mathbf{1})$ and $\left[\mathrm{ZnL}^{2}\left(\mu_{1,1}-\mathrm{N}_{3}\right)\right]_{\mathrm{n}}(\mathbf{2})$, where $\mathrm{L}^{1}$ is the dianionic form of $N, N^{\prime}$-bis(3,5-difluoro-2-hydroxybenzylidene)-1,3-diaminopropane, and $\mathrm{L}^{2}$ is the monoanionic form of 2-[(2-dimethylaminoethylimino)methyl]-4,6-difluorophenol, have been prepared and structurally characterized by elemental analyses, IR and UV-Vis spectroscopy, as well as single-crystal X-ray diffraction. In complex 1, the $\mathrm{Zn}$ atom is in octahedral coordination, with the donor atoms of the Schiff base ligands $\mathrm{L}^{1}$ and one water $\mathrm{O}$ atom. In complex $\mathbf{2}$, the $\mathrm{Zn}$ atom is in trigonal-bipyramidal coordination, with the three donor atoms of the Schiff base ligand $\mathrm{L}^{2}$ and two azido $\mathrm{N}$ atoms. The complexes have strong antibacterial activity against B. subtilis and S. aureus.
\end{abstract}

Keywords: Schiff base; zinc complex; hydrogen bonds; crystal structure; antibacterial activity

\section{Introduction}

The rational design and preparation of new coordination compounds have attracted remarkable attention in coordination chemistry. ${ }^{1}$ Azide anion is an interesting ligand in the self-assembly of new structures of complexes. A variety of azido complexes with discrete or one-, two-, and three-dimensional polymeric structures have been reported. ${ }^{2}$ Schiff bases derived from salicylaldehyde and its derivatives usually possess two or more donor atoms, which can chelate to transition metal atoms, to form a variety of complexes. ${ }^{3}$ Metal complexes with Schiff base ligands have attracted much attention in the fields of magnetic, catalytic, as well as biological materials. ${ }^{4}$ Zinc complexes with Schiff base ligands are reported to have interesting antibacterial activities. ${ }^{5}$ As a continuation of the work on Schiff base complexes, and to explore new and effective antibacterial materials, we report here the synthesis, characterization, and self-assembly of two new zinc(II) complexes, $\left[\mathrm{Zn}_{2}\left(\mathrm{~L}^{1}\right)_{2}\left(\mathrm{OH}_{2}\right)_{2}\right](\mathbf{1})$ and $\left[\mathrm{ZnL}^{2}\left(\mu_{1,1}-\mathrm{N}_{3}\right)\right]_{\mathrm{n}}(\mathbf{2})$, where $\mathrm{L}^{1}$ is the dianionic form of $N, N^{\prime}$-bis(3,5-difluoro-2-hydroxybenzylidene)-1,3-diaminopropane, and $\mathrm{L}^{2}$ is the monoanionic form of 2-[(2-dimethylaminoethylimino)methyl]-4,6-difluorophenol. The antibacterial activities of the complexes were investigated.

\section{Experimental}

\section{1. Materials and Physical Measurements}

3,5-Difluorosalicylaldehyde, propane-1,3-diamine and $\mathrm{N}, \mathrm{N}$-dimethylethane-1,2-diamine were purchased from Aldrich. All other reagents and solvents used in the synthesis were procured commercially and used without subsequent purification. The Schiff bases were synthesized according to the literature method. ${ }^{6}$ Microanalyses $(\mathrm{C}, \mathrm{H}, \mathrm{N})$ were performed using a Perkin-Elmer 2400 elemental analyzer. Infrared spectra were measured on $\mathrm{KBr}$ 
disks with a Hitachi I-5040 FT-IR spectrophotometer. Electronic spectra were measured with a Lambda 35 spectrophotometer. Single crystal X-ray data were collected on a Bruker SMART APEX II diffractometer.

Caution! Azide complexes of metal ions are potentially explosive. Only a small amount of material should be prepared, and they should be handled with caution.

\section{2. Synthesis of Complex 1}

A methanol solution $(10 \mathrm{~mL})$ of zinc(II) bromide (0.10 mmol, $22.5 \mathrm{mg}$ ) was added to the methanol solution $(10 \mathrm{~mL})$ of $\mathrm{H}_{2} \mathrm{~L}^{1}(0.10 \mathrm{mmol}, 35.4 \mathrm{mg})$ and $\mathrm{NaN}_{3}(0.10$ $\mathrm{mmol}, 6.5 \mathrm{mg})$. The reaction mixture was magnetic stirred for $1 \mathrm{~h}$ at ambient temperature to give colorless solution. Single-crystals suitable for X-ray diffraction were obtained from the filtrate by slow evaporation in a refrigerator. Yield: $205 \mathrm{mg}, 47 \% . \lambda_{\max }(\mathrm{nm})\left[\varepsilon_{\max }\left(\mathrm{L} \mathrm{mol}^{-1} \mathrm{~cm}^{-1}\right)\right]$ in methanol: $270(16,550), 365(12,070)$. IR data $\left(\mathrm{KBr}, \mathrm{cm}^{-1}\right)$ : $3454(\mathrm{OH}), 1638(\mathrm{CH}=\mathrm{N}), 1461,1362,1259,1155,952$, 853, 532. Anal. calcd. for $\mathrm{C}_{34} \mathrm{H}_{28} \mathrm{~F}_{8} \mathrm{~N}_{4} \mathrm{O}_{6} \mathrm{Zn}_{2}$ (\%): C, 46.86; H, 3.24; N, 6.43. Found (\%): C, 46.67; H, 3.33; N, 6.54.

\section{3. Synthesis of Complex 2}

A methanol solution $(10 \mathrm{~mL})$ of zinc(II) bromide $(0.10 \mathrm{mmol}, 22.5 \mathrm{mg})$ was added to the methanol solution $(10 \mathrm{~mL})$ of $\mathrm{HL}^{2}(0.10 \mathrm{mmol}, 22.8 \mathrm{mg})$ and $\mathrm{NaN}_{3}(0.10$ $\mathrm{mmol}, 6.5 \mathrm{mg}$ ). The reaction mixture was magnetic stirred for $1 \mathrm{~h}$ at ambient temperature to give colorless solution. Single-crystals suitable for X-ray diffraction were obtained from the filtrate by slow evaporation in a refrigerator. Yield: $173 \mathrm{mg}, 52 \% . \lambda_{\max }(\mathrm{nm})\left[\varepsilon_{\max }\left(\mathrm{L} \mathrm{mol}^{-1} \mathrm{~cm}^{-1}\right)\right]$ in methanol: $270(17,380), 377(11,025)$. IR data $\left(\mathrm{KBr}, \mathrm{cm}^{-1}\right)$ : $2052\left(\mathrm{~N}_{3}\right), 1642(\mathrm{CH}=\mathrm{N}), 1556,1469,1353,1289,1254$, $1123,989,820,781,753,578$. Anal. calcd. for $\mathrm{C}_{11} \mathrm{H}_{13} \mathrm{~F}-$ ${ }_{2} \mathrm{~N}_{5} \mathrm{OZn}(\%)$ : C, 39.48; H, 3.92; N, 20.93. Found (\%): C, 39.27; H, 4.03; N, 20.72.

\section{4. X-ray Crystallography}

Data collection for the complexes was performed with a Bruker Apex II CCD diffractometer at $298 \mathrm{~K}$ using Mo $\mathrm{Ka}(\lambda=0.71073 \AA)$ radiation. The structures were solved by direct methods with SHELXS-97 and refined by full-matrix least squares (SHELXL-97) on $F^{2} .^{7}$ All non-hydrogen atoms were refined anisotropically. The water $\mathrm{H}$ atoms of complex 1 were located from an electronic density map and refined isotropically, with $\mathrm{O}-\mathrm{H}$ and $\mathrm{H} \cdots \mathrm{H}$ distances restrained to $0.85(1)$ and $1.37(2) \AA$, respectively. The remaining hydrogen atoms were placed geometrically and refined with a riding model, with isotropic displacement coefficients $U(\mathrm{H})=1.2 U(\mathrm{C})$ or $1.5 U\left(\mathrm{C}_{\text {methyl }}\right)$. Crystallographic data for the complexes are summarized in Table 1. Selected bond lengths and angles are listed in Table 2 .
Table 1. Crystallographic data for the complexes

\begin{tabular}{|c|c|c|}
\hline & 1 & 2 \\
\hline Empirical formula & $\mathrm{C}_{34} \mathrm{H}_{28} \mathrm{~F}_{8} \mathrm{~N}_{4} \mathrm{O}_{6} \mathrm{Zn}_{2}$ & $\mathrm{C}_{11} \mathrm{H}_{13} \mathrm{~F}_{2} \mathrm{~N}_{5} \mathrm{OZn}$ \\
\hline Formula weight & 871.34 & 334.63 \\
\hline Crystal system & Triclinic & Monoclinic \\
\hline Space group & $P-1$ & $P 2_{1} / c$ \\
\hline$a / \AA$ & $6.9736(8)$ & $20.034(2)$ \\
\hline$b / \AA$ & $10.8352(12)$ & $10.1610(17)$ \\
\hline$c / \AA$ & $11.3007(13)$ & $6.7339(12)$ \\
\hline$\alpha /{ }^{\circ}$ & $75.958(2)$ & 90 \\
\hline$\beta / \mathrm{o}$ & $89.667(2)$ & $92.477(2)$ \\
\hline$\gamma / \mathrm{o}$ & $79.652(2)$ & 90 \\
\hline $\mathrm{V} / \AA^{3}$ & $814.26(16)$ & $1369.5(4)$ \\
\hline $\mathrm{Z}$ & 1 & 4 \\
\hline$D_{\text {calc }} / \mathrm{g} \mathrm{cm}^{-3}$ & 1.777 & 1.623 \\
\hline Crystal size /mm & $0.33 \times 0.30 \times 0.28$ & $0.16 \times 0.15 \times 0.15$ \\
\hline$\mu(\mathrm{Mo} \mathrm{Ka}) / \mathrm{mm}^{-1}$ & 1.574 & 1.819 \\
\hline$F(000)$ & 440 & 680 \\
\hline Number of reflections & 4324 & 4580 \\
\hline Unique reflections & 3004 & 1946 \\
\hline $\begin{array}{l}\text { Observed reflections } \\
(I>2 \sigma(I))\end{array}$ & 2527 & 1055 \\
\hline Parameters & 250 & 183 \\
\hline Restraints & 3 & 0 \\
\hline$R_{\mathrm{int}}$ & 0.0125 & 0.1137 \\
\hline Goodness of fit on $F^{2}$ & 1.047 & 0.971 \\
\hline$R_{1}, w R_{2}(I>2 \sigma(I))$ & $0.0345,0.0739$ & $0.0863,0.1668$ \\
\hline$R_{1}, w R_{2}$ (all data) & $0.0455,0.0792$ & $0.1553,0.2087$ \\
\hline
\end{tabular}

Table 2. Selected bond lengths ( $\AA$ ) and angles $\left(^{\circ}\right)$ for the complexes with estimated standard deviations (e.s.d.s) in parentheses

\begin{tabular}{lrlr}
\hline 1 & & & \\
\hline Zn1-O1 & $2.0519(18)$ & Zn1-O2 & $2.0073(17)$ \\
Zn1-N1 & $2.091(2)$ & Zn1-N2 & $2.126(2)$ \\
Zn1-O3 & $2.201(2)$ & Zn1-O1A & $2.560(2)$ \\
O2-Zn1-O1 & $89.14(7)$ & O2-Zn1-N1 & $176.20(8)$ \\
O1-Zn1-N1 & $87.05(8)$ & O2-Zn1-N2 & $88.87(8)$ \\
O1-Zn1-N2 & $170.55(9)$ & N1-Zn1-N2 & $94.91(8)$ \\
O2-Zn1-O3 & $90.32(8)$ & O1-Zn1-O3 & $96.92(9)$ \\
N1-Zn1-O3 & $90.00(9)$ & N2-Zn1-O3 & $92.33(8)$ \\
N1-Zn1-O1A & $86.31(9)$ & N2-Zn1-O1A & $88.72(9)$ \\
O1-Zn1-O1A & $82.17(9)$ & O2-Zn1-O1A & $93.31(9)$ \\
O3-Zn1-O1A & $176.24(9)$ & & \\
\hline 2 & & & \\
\hline Zn1-O1 & $2.024(8)$ & Zn1-N1 & $2.055(8)$ \\
Zn1-N2 & $2.280(9)$ & Zn1-N3 & $2.053(8)$ \\
Zn1-N3B & $2.097(8)$ & & \\
O1-Zn1-N3 & $94.2(4)$ & O1-Zn1-N1 & $88.7(3)$ \\
N3-Zn1-N1 & $127.6(3)$ & O1-Zn1-N3B & $92.5(3)$ \\
N3-Zn1-N3B & $108.5(3)$ & N1-Zn1-N3B & $123.6(3)$ \\
O1-Zn1-N2 & $169.8(3)$ & N3-Zn1-N2 & $93.1(4)$ \\
N1-Zn1-N2 & $81.2(3)$ & N3A-Zn1-N2 & $91.8(3)$ \\
\hline
\end{tabular}

Symmetry codes: A: $-x, 1-y, 1-z ; \mathrm{B}: x, 1 / 2-y, 1 / 2+z$. 


\subsection{Antibacterial Activity}

The antibacterial activities were tested against B. subtilis ATCC 6633, E. coli ATCC 35218, P. putida TS 1138 and S. aureus ATCC 25923 using MH medium (MuellerHinton medium: casein hydrolysate $17.5 \mathrm{~g}$, soluble starch $1.5 \mathrm{~g}$, beef extract $1000 \mathrm{~mL}$ ). The MICs (minimum inhibitory concentrations) of the test compounds were determined by a colorimetric method using the dye MTT [3-(4,5-dimethylthiazol-2-yl)-2,5-diphenyl tetrazolium bromide]. A stock solution of the synthesized compound $\left(50 \mu \mathrm{g} \mathrm{mL}^{-1}\right)$ in DMSO was prepared and quantities of the test compounds were incorporated in specified quantity of sterilized liquid MH medium. A specified quantity of the medium containing the compound was poured into microtitration plates. A suspension of the microorganism was prepared to contain approximately $10^{5} \mathrm{cfu} \mathrm{mL}^{-1}$ and applied to micro-titration plates with serially diluted compounds in DMSO to be tested and incubated at $37^{\circ} \mathrm{C}$ for $24 \mathrm{~h}$. After the MICs were visually determined on each of the micro-titration plates, $50 \mu \mathrm{L}$ of PBS (phosphate buffered saline $0.01 \mathrm{~mol} \mathrm{~L}-1$, $\mathrm{pH}$ 7.4: $\mathrm{Na}_{2} \mathrm{HPO}_{4} 2.9 \mathrm{~g}, \mathrm{KH}_{2} \mathrm{PO}_{4}$ $0.2 \mathrm{~g}, \mathrm{NaCl} 8.0 \mathrm{~g}, \mathrm{KCl} 0.2 \mathrm{~g}$, distilled water $1000 \mathrm{~mL}$ ) containing $2 \mathrm{mg}$ of MTT per $\mathrm{mL}^{-1}$ was added to each well. Incubation was continued at room temperature for $4-5 \mathrm{~h}$. The content of each well was removed and $100 \mu \mathrm{L}$ of isopropanol containing $5 \% \mathrm{HCl}\left(1 \mathrm{~mol} \mathrm{~L}^{-1}\right)$ was added to extract the dye. After $12 \mathrm{~h}$ of incubation at room temperature, the optical density (OD) was measured with a microplate reader at $550 \mathrm{~nm}$.

\section{Results and Discussion}

\section{1. Synthesis}

The complexes were prepared by reaction of equimolar quantities of the Schiff base ligands with zinc bromide and sodium azide in methanol. It is interesting that the azide anion did not coordinate to the $\mathrm{Zn}$ atom in complex $\mathbf{1}$, and the bromide anion did not coordinate to the $\mathrm{Zn}$ atom in complex 2 . Crystals of the complexes are stable in air, and soluble in methanol, ethanol, DMF and DMSO, insoluble in water. The molar conductance of the complexes is $27 \Omega^{-1} \mathrm{~cm}^{2} \mathrm{~mol}^{-1}$ for $\mathbf{1}$ and $19 \Omega^{-1} \mathrm{~cm}^{2} \mathrm{~mol}^{-1}$ for $\mathbf{2}$, indicating that the complexes are non-electrolytes.

\section{2. Description of the Structure of Complex 1}

Complex 1 is a phenolate oxygen bridged dinuclear zinc(II) compound, with the $\mathrm{Zn} \cdots \mathrm{Zn}$ distance of 3.492(2) $\AA$ (Figure 1). The molecule of the complex possesses crystallographic inversion center symmetry, with the inversion center located at the midpoint of the two $\mathrm{Zn}$ atoms. The $\mathrm{Zn}$ atom is in octahedral coordination, with the phenolate oxygen and imino nitrogen of one Schiff base ligand defining the equatorial plane, and with the phenolate oxygen of the other Schiff base ligand and one water $\mathrm{O}$ atom occupying the axial positions. The $\mathrm{Zn}-\mathrm{O}$ and $\mathrm{Zn}-\mathrm{N}$ bond lengths in the equatorial plane involving donor atoms from the Schiff base ligand are $\mathrm{Zn} 1-\mathrm{O} 1$

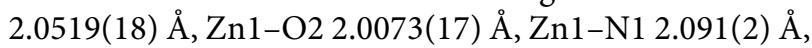
and $\mathrm{Zn} 1-\mathrm{N} 22.126(2) \AA$. . The $\mathrm{Zn}-\mathrm{O}$ bond lengths in the axial positions are Zn1-O3 2.201(2) $\AA$ and Zn1-O1A 2.560(2) $\AA$, which are much longer than those in the equatorial plane. The $\mathrm{Zn}-\mathrm{O}$ and $\mathrm{Zn}-\mathrm{N}$ bond lengths in the complex are comparable to those reported for Schiff

Table 3. Hydrogen bond distances $(\AA)$ and bond angles $\left(^{\circ}\right)$ for complex 1

\begin{tabular}{|c|c|c|c|c|}
\hline$D-\mathrm{H} \cdots A$ & $d(D-H)$ & $d(\mathrm{H} \cdots A)$ & $d(D \cdots A)$ & $\begin{array}{c}\text { Angle } \\
(D-\mathrm{H} \cdots A)\end{array}$ \\
\hline $\mathrm{O} 3-\mathrm{H} 3 \mathrm{~A} \cdots \mathrm{F} 1^{\#}$ & $0.85(1)$ & $2.27(2)$ & $3.057(3)$ & $155(3)$ \\
\hline $\mathrm{O} 3-\mathrm{H} 3 \mathrm{~A} \cdots \mathrm{O} 1^{\#}$ & $0.85(1)$ & $2.44(3)$ & $3.099(3)$ & $135(3)$ \\
\hline $\mathrm{O} 3-\mathrm{H} 3 \mathrm{~B} \cdots \mathrm{O} 2^{\#}$ & $0.85(1)$ & $1.96(2)$ & $2.746(3)$ & $155(3)$ \\
\hline $\mathrm{O} 3-\mathrm{H} 3 \mathrm{~B} \cdots \mathrm{F} 3^{\#}$ & $0.85(1)$ & $2.52(3)$ & $3.119(3)$ & $128(3)$ \\
\hline
\end{tabular}

Symmetry code for $\#: 1-x, 1-y, 1-z$.

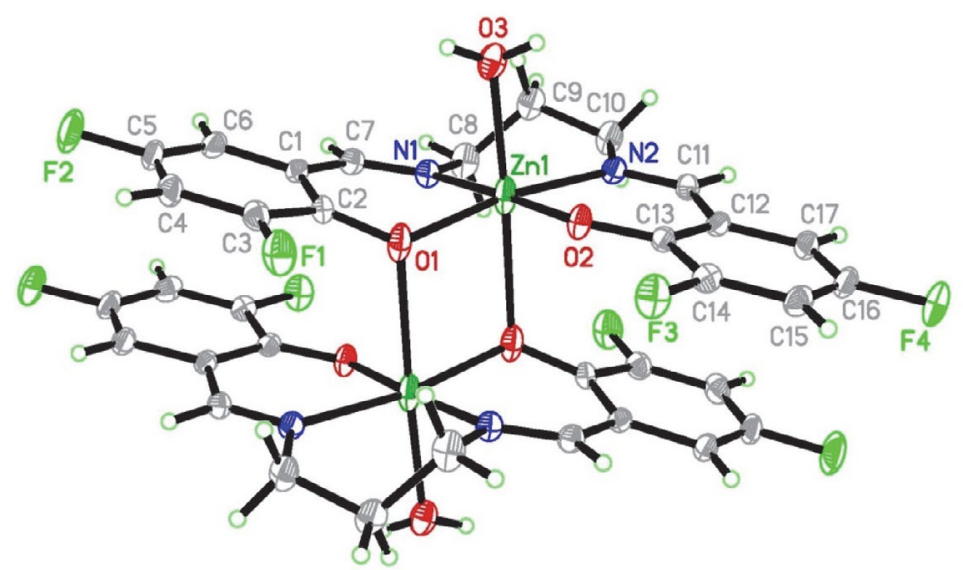

Figure 1. Molecular structure of complex 1, with $30 \%$ thermal probability. Unlabeled atoms are at the symmetry position $-x, 1-y, 1-z$. 


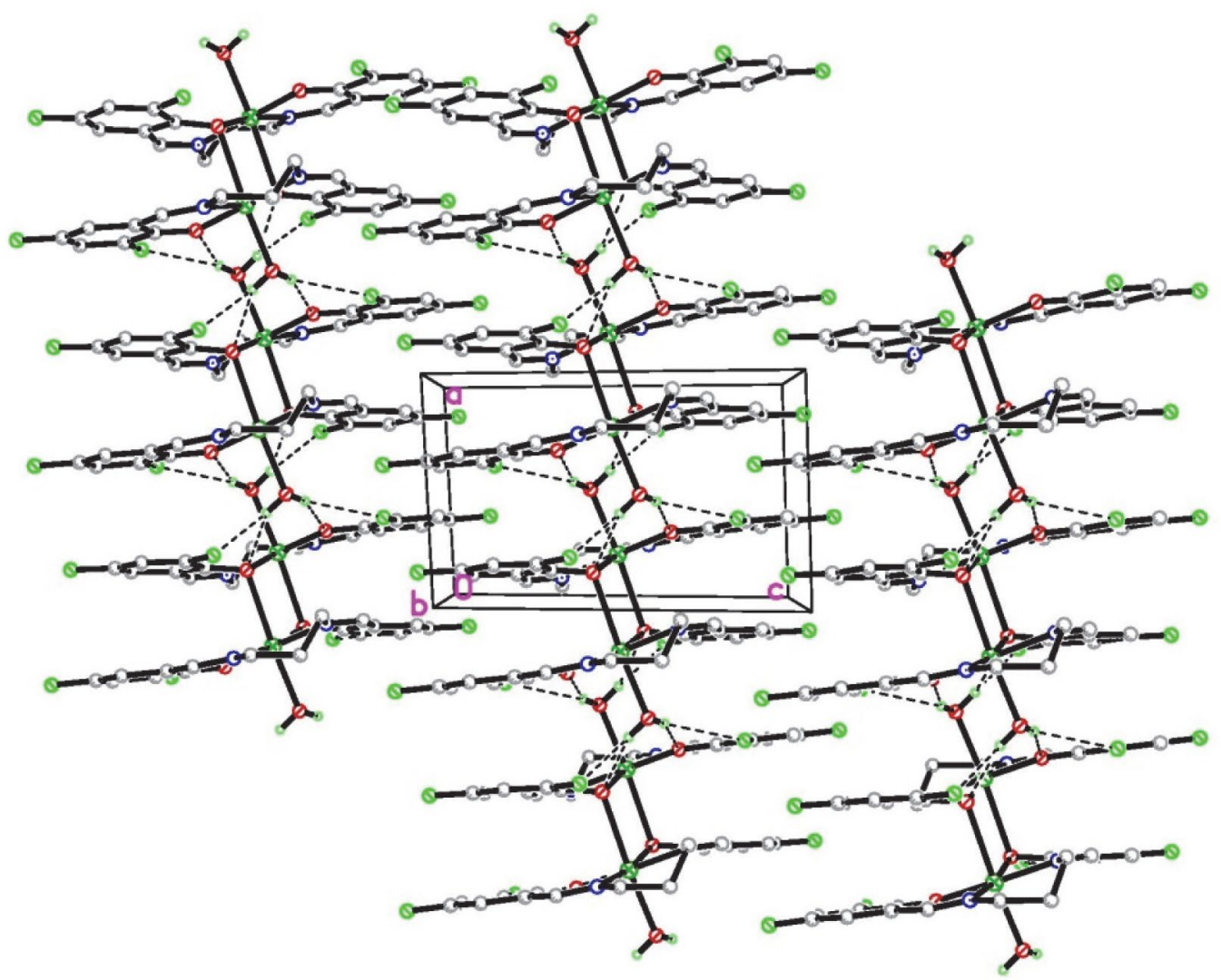

Figure 2. The hydrogen linked structure of complex 1, viewed along the axis- $b$ direction. Hydrogen bonds are shown as dashed lines.

base zinc(II) complexes. ${ }^{8}$ As is apparent from Table 2, there are only slight deviation from an ideal octahedral geometry, with all cis angles within $7^{\circ}$ of $90^{\circ}$, with the exception of the chelating O1-Zn1-O1A angle of $82.17(9)^{\circ}$. The four atoms in the equatorial plane, $\mathrm{O} 1, \mathrm{O} 2$, $\mathrm{N} 1$ and $\mathrm{N} 2$, are approximately in a plane, with mean deviation of 0.082(3) $\AA$, and with the Zn atom being 0.086(2) $\AA$ from the plane in the direction of O3.

In the crystal structure of the complex, the water ligands participate in the hydrogen bonds with the phenolate oxygen and fluorine groups of the Schiff base ligands. The molecules are linked through $\mathrm{O}-\mathrm{H} \cdots \mathrm{O}$ and $\mathrm{O}-\mathrm{H} \cdots \mathrm{F}$ hydrogen bonds (Table 3), to form chains running along the $a$ axis (Figure 2).

\section{3. Description of the Structure of Complex 2}

Complex $\mathbf{2}$ is an end-on azido-bridged polynuclear zinc(II) compound, with the $\mathrm{Zn}$...Zn distance of 3.533(2) $\AA$ (Figure 3). The $\mathrm{Zn}$ atom is in a trigonal bipyramidal coordination, with the imino nitrogen of the Schiff base ligand and two azido nitrogen defining the basal plane, and with the phenolate oxygen and amino nitrogen occupying the axial positions. The $\mathrm{Zn}-\mathrm{N}$ bond lengths in the basal plane involving donor atoms from the Schiff base and azide ligands are Zn1-N1 2.055(8) $\AA$, Zn1-N3 2.053(8) , and $\mathrm{Zn} 1-\mathrm{N} 3 \mathrm{~B}$ 2.097(8) $\AA$. The $\mathrm{Zn}-\mathrm{O}$ and $\mathrm{Zn}-\mathrm{N}$ bond lengths in the axial positions are Zn1-O1 2.024(8) $\AA$ and $\mathrm{Zn} 1-\mathrm{N} 2$ 2.280(9) $\AA$. The $\mathrm{Zn}-\mathrm{O}$ and $\mathrm{Zn}-\mathrm{N}$ bond lengths in the complex are similar to those of complex 1 , and also comparable to those reported for Schiff base zinc(II) com-

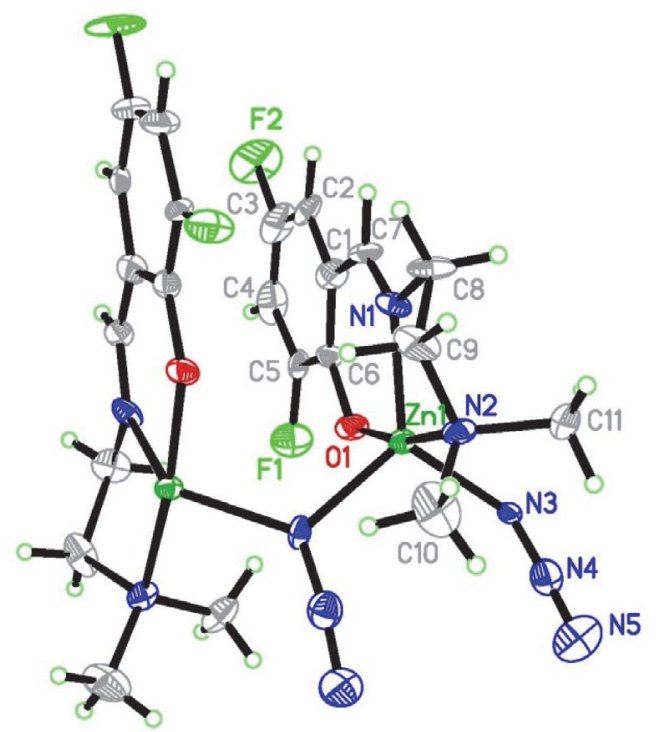

Figure 3. Molecular structure of complex 2, with $30 \%$ thermal probability. Unlabeled atoms are at the symmetry position $x, 1 / 2-y$, $1 / 2+z$. 


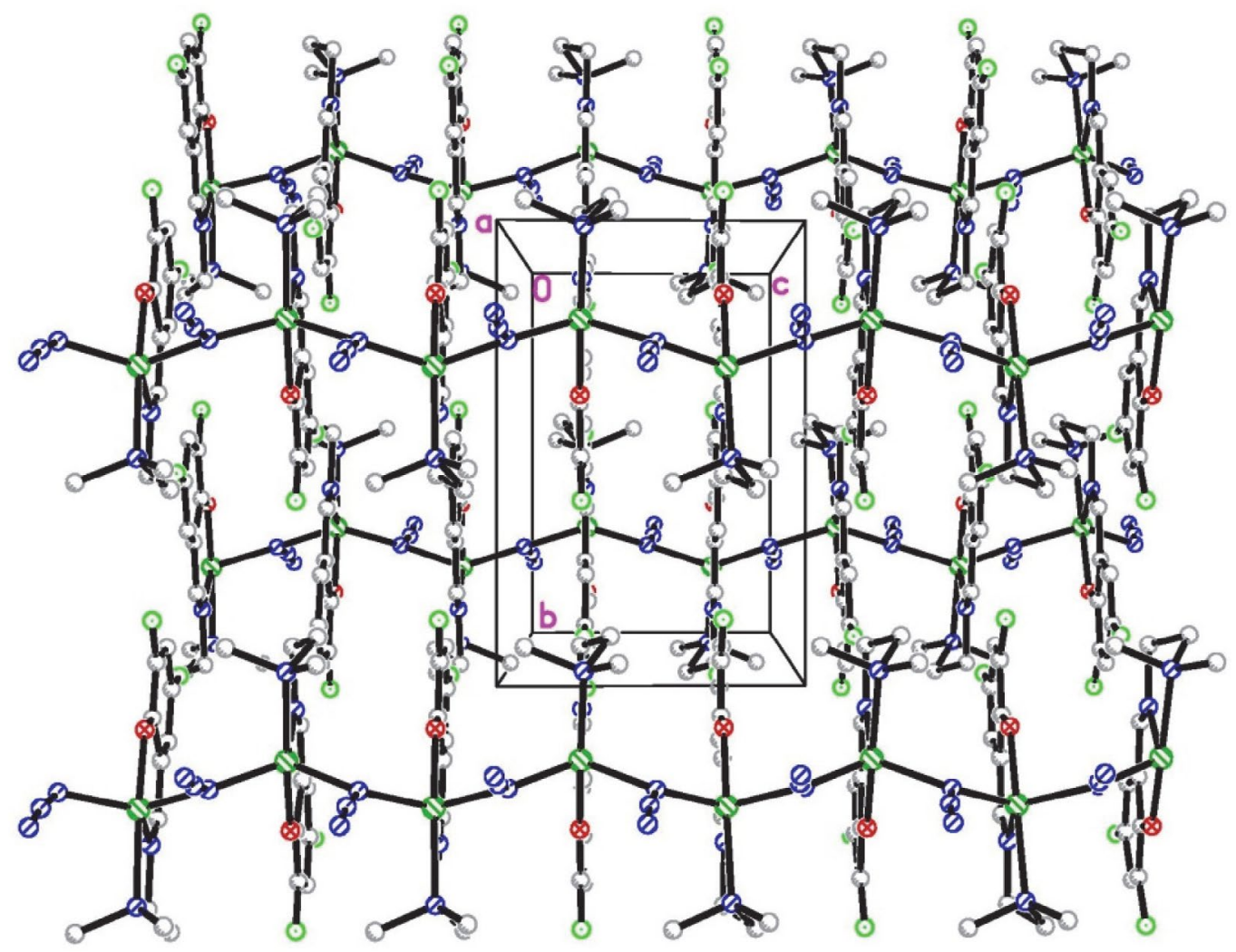

Figure 4. The end-on azido bridged polynuclear structure of complex 2 , viewed along the axis- $a$ direction.

plexes. ${ }^{9}$ As is apparent from Table 2, there are only slight deviation from an ideal trigonal bipyramidal geometry, with the angles at the basal plane within $12^{\circ}$ of $120^{\circ}$. The three atoms in the basal plane, N1, N3 and N3B, are coplar, and with the $\mathrm{Zn}$ atom being 0.060(2) $\AA$ from the plane in the direction of $\mathrm{O} 1$. The $\left[\mathrm{ZnL}^{2}\right]$ moieties are linked through end-on azido bridges, to form chains running along the $c$ axis (Figure 4).

The question arises as to whether the coordination polyhedron around the five-coordinated zinc atom can be described as a distorted square pyramid or a distorted trigonal bipyramid. Further information can be obtained by determining the structural index $\tau$ which represents the relative amount of trigonality (square pyramid, $\tau=0$; trigonal bipyramid, $\tau=1) ; \tau=(\beta-\alpha) / 60^{\circ}, \alpha$ and $\beta$ being the two largest angles around the central atom. ${ }^{10}$ The values of $\tau$ is 0.70 . The coordination geometry of the zinc atom in this complex is therefore approximately described as a trigonal bipyramid.

\section{4. Spectral Characterization}

In the infrared spectra of the complexes, the bands corresponding to the azomethine $(\mathrm{CH}=\mathrm{N})$ groups are observed at $1638 \mathrm{~cm}^{-1}$ for 1 and $1642 \mathrm{~cm}^{-1}$ for $2 .{ }^{11}$ The typical absorptions for the azide ligand in 2 is located at 2052 $\mathrm{cm}^{-1} .{ }^{12}$ The appearance of the band at $1353 \mathrm{~cm}^{-1}$ indicates the asymmetric nature of the azide groups in complex 2 . The weak and broad band centered at $3512 \mathrm{~cm}^{-1}$ for $\mathbf{1}$ is ascribes to the $\mathrm{O}-\mathrm{H}$ vibrations of the water ligands. The weak bands in the region of $420-570 \mathrm{~cm}^{-1}$ for the complexes can be assigned to $v(\mathrm{Zn}-\mathrm{N})$ and $v(\mathrm{Zn}-\mathrm{O})$. The electronic spectra of the complexes were recorded using the methanol as solvent. The absorptions appear in the range 270-380 $\mathrm{nm}$ are most likely due to the $\pi \rightarrow \pi^{\star}$ transitions and ligand-to-metal charge transfer.

\section{5. Antibacterial Activity}

The complexes were screened for antibacterial activity against $B$. subtilis ATCC 6633, E. coli ATCC 35218, $P$. putida TS 1138 and S. aureus ATCC 25923 by the MTT method. The MIC values of the complexes against these bacteria are presented in Table 4 . The antibiotic Penicillin was included as a reference. In general, the two zinc complexes have effective activities against the bacteria $B$. subtilis and $S$. aureus, medium activity against $E$. coli, and weak activity agaist $P$. putida. It is interesting that for B. subtilis, complex 1 has the most activity with MIC value of $0.39 \mu \mathrm{g}$ $\mathrm{mL}^{-1}$, and for $S$. aureus, complexes $\mathbf{1}$ and $\mathbf{2}$ have effective activity with MIC values of 0.39 and $0.78 \mu \mathrm{g} \mathrm{mL}^{-1}$, respectively. So, the complexes showed a wide range of bactericidal activities against the bacteria, more potent than, or similar with, commercial antibiotic Penicillin. 
Table 4. MIC $\left(\mu \mathrm{g} \mathrm{mL}^{-1}\right)$ values of the antibacterial activity of the complexes

\begin{tabular}{ccccc}
\hline Compound & B. subtilis & E. coli & P. putida & S. aureus \\
\hline 1 & 0.39 & 12.5 & 25.0 & 0.39 \\
2 & 1.56 & 25.0 & 50.0 & 0.78 \\
Penicillin & 0.78 & $>100$ & 12.5 & 3.13 \\
\hline
\end{tabular}

\section{Conclusion}

A new phenolate oxygen bridged dinuclear zinc(II) complex and a new end-on azido-bridged polynuclear zinc(II) complex have been prepared and structurally characterized in this article. The dianionic Schiff base ligand in the phenolate oxygen bridged complex coordinates to the $\mathrm{Zn}$ atom through the phenolate oxygen and imino nitrogen. The monoanionic Schiff base ligand in the end-on azido bridged complex coordinates to the $\mathrm{Zn}$ atom through the phenolate oxygen, imino nitrogen and amino nitrogen. During the self-assembly of the complexes, the bis-Schiff base zinc complex choose the neutral water molecule as co-ligand, while the mono-Schiff base zinc complex choose the azide as co-ligand. The complexes have strong antibacterial activity against $B$. subtilis and $S$. aureus.

\section{Supplementary Data}

Crystallographic data for the analysis have been deposited with the Cambridge Crystallographic Data Centre, CCDC Nos. 1848822 (1) and 1848823 (2). Copies of this information may be obtained free of charge from CCDC, 12 Union Road, Cambridge CB2 1EZ, UK (fax: +44 1223 336 033; e-mail: deposit@ccdc.cam.ac.uk or www: http:// www.ccdc.cam.ac.uk).

\section{Acknowledgments}

This work was supported by Zhengzhou University of Light Industry.

\section{References}

1. (a) R. A. Baglia, J. P. T. Zaragoza, D. P. Goldberg, Chem. Rev. 2017, 117, 13320-13352; DOI:10.1021/acs.chemrev.7b00180 (b) S. E. Sherman, Q. Xiao, V. Percec, Chem. Rev. 2017, 117, 6538-6631; DOI:10.1021/acs.chemrev.7b00097

(c) A. J. Jasniewski, L. Que, Chem. Rev. 2018, 118, 2554-2592. DOI:10.1021/acs.chemrev.7b00457

2. (a) A. Hazari, C. Diaz, A. Ghosh, Polyhedron 2018, 142, 16-24; DOI:10.1016/j.poly.2017.12.022

(b) D. Bandyopadhyay, M. Layek, M. Fleck, R. Saha, C. Rizzoli, Inorg. Chim. Acta 2017, 461, 174-182;

\section{DOI:10.1016/j.ica.2017.02.018}

(c) M. Zhang, D.-M. Xian, N. Zhang, Z.-L. You, J. Coord. Chem. 2012, 65, 1837-1846.

DOI:10.1080/00958972.2012.684383

3. (a) A. B. Deilami, M. Salehi, A. Arab, A. Amiri, Inorg. Chim. Acta 2018, 476, 93-100; DOI:10.1016/j.ica.2018.02.013

(b) T. Basak, K. Ghosh, C. J. Gomez-Garcia, S. Chattopadhyay, Polyhedron 2018, 146, 42-54;

DOI:10.1016/j.poly.2017.12.040

(c) J. Wang, D. Qu, J.-X. Lei, Z. You, J. Coord. Chem. 2017, 70, 544-555; DOI:10.1080/00958972.2016.1262538

(d) L.-X. Li, Y. Sun, Q. Xie, Y.-B. Sun, K.-H. Li, Z.-L. You, Chinese J. Inorg. Chem. 2016, 32, 369-376.

4. (a) G. Kumaravel, P. P. Utthra, N. Raman, Bioorg. Chem. 2018, 77, 269-279; DOI:10.1016/j.bioorg.2018.01.024

(b) S. M. Daskalova, X. H. Bai, S. M. Hecht, Biochem. 2018, 57, 2711-2722. DOI:10.1021/acs.biochem.8b00308

5. (a) Z. H. Chohan, M. Arif, A. Rashid, J. Enzyme Inhib. Med. Chem. 2008, 23, 785-796; DOI:10.1080/14756360701450145 (b) H. T. Y. L. K. Wah, S. Bangarigadu-Sanasy, Asian J. Chem. 2013, 25, 9221-9225;

(c) H. Keypour, A. Shooshtari, M. Rezaeivala, F. Mohsenzadeh, H. A. Rudbari, Transition Met. Chem. 2015, 40, 715-722; (d) W. G. Zhang, J. H. Liang, Russ. J. Coord. Chem. 2017, 43, 540-546.

6. (a) G. G. Mohamed, E. M. Zayed, A. M. M. Hindy, Spectrochim. Acta A-Mol. Biomol. Spectrosc. 2015, 145, 76-84;

DOI:10.1016/j.saa.2015.01.129

(b) M. Salehi, A. Amoozadeh, A. Salamatmanesh, M. Kubicki, G. Dutkiewicz, S. Samiee, A. Khaleghian, J. Mol. Struct. 2015, 1091, 81-87; DOI:10.1016/j.molstruc.2015.02.060

(c) A. Goszczynska, H. Kwiecien, K. Fijalkowski, Med. Chem. Res. 2015, 24, 3561-3577;

DOI:10.1007/s00044-015-1397-6

(d) A. E. Amr, M. A. Al-Omar, Russ. J. Gen. Chem. 2016, 86, 161-166. DOI:10.1134/S1070328417080085

DOI:10.1134/S1070363216010254

7. G. M. Sheldrick, Acta Crystallogr. 2008, A64, 112-122. DOI:10.1107/S0108767307043930

8. (a) H. Keypour, A. Shooshtari, M. Rezaeivala, F. Mhosenzadeh, H. A. Rudbari, Transition Met. Chem. 2015, 40, 715-722; (b) M. Montazerozohori, S. Farokhiyani, A. Masoudiasl, J. M. White, RSC Adv. 2016, 6, 23866-23878;

(c) S. Shit, M. Nandy, D. Saha, L. Zhang, W. Schmitt, C. Rizzoli, T. N. G. Row, J. Coord. Chem. 2016, 69, 2403-2414; DOI:10.1080/00958972.2016.1197390

(d) J. Qin, Z. N. Xia, Y. Zhang, F. Niu, Z. L. You, H. L. Zhu, Synth. React. Inorg. Met.-Org. Nano-Met. Chem. 2016, 46, 1805-1809; DOI:10.1080/15533174.2015.1137065

(e) J. Qin, Y. Sun, Z. N. Xia, Y. Zhang, X. L. Zhao, Z. L. You, H. L. Zhu, Russ. J. Coord. Chem. 2016, 42, 330-337. DOI:10.1134/S1070328416050055

9. (a) S. Saeednia, P. Iranmanesh, M. H. Ardakani, M. Mohammadi, G. Norouzi, Mater. Res. Bull. 2016, 78, 1-10;

DOI:10.1016/j.materresbull.2016.02.010

(b) M. A. Aldamen, N. Charef, H. K. Juwhari, K. Sweidan, 
M. S. Mubarak, D. G. Peters, J. Chem. Crystallogr. 2016, 46, 411-420; DOI:10.1007/s10870-016-0670-y

(c) M. Jafari, M. Salehi, M. Kubicki, A. Arab, A. Khaleghian, Inorg. Chim. Acta 2017, 462, 329-335;

DOI:10.1016/j.ica.2017.04.007

(d) D. Majumdar, J. K. Biswas, M. Mondal, M. S. S. Babu, R. K. Metre, S. Das, K. Bankura, D. Mishra, J. Mol. Struct. 2018, 1155, 745-757. DOI:10.1016/j.molstruc.2017.11.052
10. A. W. Addison, T. N. Rao, J. Reedijk, J. van Rijn, G. C. Verschoor, J. Chem. Soc. Dalton Trans. 1984, 1349-1356. DOI:10.1039/DT9840001349

11. S. A. Patil, V. H. Naik, A. D. Kulkarni, P. S. Badami, Spectrochim. Acta A, 2010, 75, 347-354.

DOI:10.1016/j.saa.2009.10.039

12. S. Jana, P. Bhowmik, M. Das, P. P. Jana, K. Harms, S. Chattopadhyay, Polyhedron 2012, 37, 21-26.

DOI:10.1016/j.poly.2012.01.031

\section{Povzetek}

Sintetizirali smo dva cinkova(II) kompleksa, $\left[\mathrm{Zn}_{2}\left(\mathrm{~L}^{1}\right)_{2}\left(\mathrm{OH}_{2}\right)_{2}\right](\mathbf{1})$ in $\left[\mathrm{ZnL}^{2}\left(\mu_{1,1}-\mathrm{N}_{3}\right)\right]_{\mathrm{n}}(2)$, kjer je $\mathrm{L}^{1}$ dianionska oblika $N, N^{\prime}$-bis(3,5-difluoro-2-hidroksibenziliden)-1,3-diaminopropana, in L ${ }^{2}$ monoanionska oblika 2-[(2-dimetilaminoetilimino)metil]-4,6-difluorofenola, ter ju okarakterizirali z elementno analizo, IR in UV-Vis spektroskopijo ter rentgensko difrakcijo. V kompleksu 1 je Zn atom oktaedrično koordiniran $\mathrm{z}$ donorskimi atomi liganda Schiffove baze $\mathrm{L}^{1}$ in enim kisikovim atomom molekule vode. V kompleksu 2 je $\mathrm{Zn}$ atom trikotno-bipiramidalno koordiniran s tremi donorskimi atomi Schiffove baze $\mathrm{L}^{2}$ in dveh atomov dušika $\mathrm{z}$ azidnih ionov. Kompleksa izkazujeta močno protibakterijsko aktivnost proti B. subtilis in S. aureus. 